
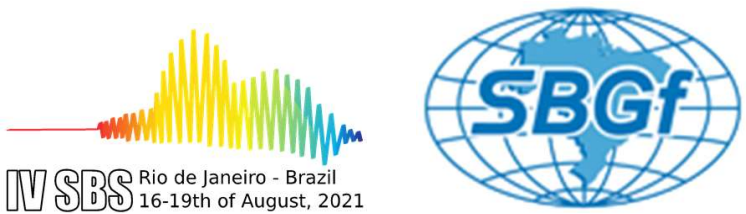

\title{
Application of the geophysical technique of pole-dipole resistivity to the detection of impermeability of dams in Quipan - Peru
}

Christ Jesus Barriga Paria, National University of Moquegua, Peru

Jorge Pantaleon Barriga Gamarra, National University Jorge Basadre Grohmann, Peru

Eleonardo Lucas Pereira, Federal University of Ouro Preto, Brazil

Copyright 2021, SBGf - Sociedade Brasileira de Geofísica.

This paper was prepared for presentation during the $17^{\text {th }}$ International Congress of the Brazilian Geophysical Society held in Rio de Janeiro, Brazil, $16-19$ August 2021.

Contents of this paper were reviewed by the Technical Committee of the $17^{\text {th }}$ International Congress of the Brazilian Geophysical Society and do not necessarily represent any position of the SBGf, its officers or members. Electronic reproduction or storage of any part of this paper for commercial purposes without the written consent of the Brazilian Geophysical Society is prohibited.

\begin{abstract}
Impermeability is one of the main objectives in the construction of a dam, and its control over its operation becomes a constant need to ensure the supply of water for irrigation of land and protect agricultural production. Quipan has three dams located at an approximate height of 3550 masl, where a geophysical investigation was developed by measurements of electrical resistivity with a pole-dipole configuration with a set of linear electrodes. With a focused character to obtain detailed information of the stratigraphy where the foundations are located and to identify the zones of weakening in the axis of the dam, in this way to have the diagnosis of the tightness of the same, which assumes that at adjacent points the variation of the resistivity cannot exceed $\pm 25 \%$, in case of major variations, a list of points to which the data collection, in case of coincidence the value is taken as true or is replaced, and those made in the cabinet with the use of Res2Dinv software for the processing of the field data. Concluded the hydraulic pressure and erosion are generating deterioration in the structure, it is even possible to highlight that the seismic activity of the area has compromised to reduce the structure resistance.
\end{abstract}

